\title{
Assessment on the lung injury of mice posed by airborne PM2.5 collected from developing area in China and associated molecular mechanisms: from histopathology to integrated transcriptome analysis
}

Shuiping Dai

Sichuan University West China Hospital

Zhenglu Wang

Colleage of oceanography, Hohai University

Ying Yang

Sichuan University West China Hospital

Tingting Guo

Sichuan University West China Hospital

weimin li ( $\sigma$ weimin003@163.com )

Sichuan University West China Hospital

Research

Keywords: PM2.5, Lung injury, Transcriptomics, Immune system, Mid-scale city

Posted Date: October 23rd, 2020

DOI: https://doi.org/10.21203/rs.3.rs-93790/v1

License: (9) This work is licensed under a Creative Commons Attribution 4.0 International License. Read Full License 


\section{Abstract}

Background \& aims

Some epidemiological investigations have revealed airborne fine particulate matter $\left(\mathrm{PM}_{2.5}\right)$ could induce adverse effects on respiratory system of human. However, the experimental evidences of the harmful effect of $\mathrm{PM}_{2.5}$ from mid-scale city in China and associated molecular mechanisms was still scarce. In this study, we aimed to evaluate the adverse effect on the lung system of $\mathrm{PM}_{2.5}$ collected from mid-city of China and elucidate the underlying molecular mechanism through mRNA-seq and microRNA-seq integrated analysis.

Methods

We exposed male Balb/C mice to $\mathrm{PM}_{2.5}$ collected from Baoji city, China for 8 weeks $\left(298.52 \pm 25.86 \mu \mathrm{g} / \mathrm{m}^{3}\right)$ using a whole-body exposure system. Micro-CT and histopathological analyses were performed to determine the morphology and histopathology changes of lung tissues induced by $\mathrm{PM}_{2.5}$. Transcriptome (both mRNA and microRNA) sequencing and the immunohistochemistry assay were performed to reveal the associated underlying mechanisms. The contents of PAHs absorbed in the $\mathrm{PM}_{2.5}$, as well as the pearson correlation index between it and the target genes and microRNA were examined.

Results

Obvious lung injury including pulmonary dysfunction, immunological responses, and fibrosis were observed from the $\mathrm{PM}_{2.5}$ exposure group. The content of leucocyte of lung tissue was significantly increased. $\mathrm{PM}_{2.5}$ mainly induced immune pathways including B cell receptor signaling and cell adhesion molecules (CAMs). The expression levels of the associated genes and microRNA were verified using RT-qPCR. The protein expression of CD19, CD81, and PIK3CD involved into B cell receptor signaling significantly increased in exposure group. The concentrations of benzo(a)pyrene (BaP) showed a marked correlationship with the genes and microRNA.

\section{Conclusions}

$\mathrm{PM}_{2.5}$ from the mid-scale city of China caused adverse effects on lung system of mice, which was much stronger than the mega city, indicating the health risk of the air pollution in the developing area should be paid more attention. The toxicity of $\mathrm{PM}_{2.5}$ may associated with immune system response. This work for the first time provided a new sight into the molecular mechanism of $\mathrm{PM}_{2.5}$ toxicity on lung system using transcriptomics integrated analysis and help further to develop effective measures to prevent air pollution associated lung disease, especially in the developing area in China.

\section{Background}

Air pollution has been recognized may pose marked threat on human health, especially the respiratory and cardiovascular system[1, 2]. Fine particulate matter with aerodynamic diameter less than $2.5 \mu \mathrm{m}\left(\mathrm{PM}_{2.5}\right)$ as one of the important components of ambient air pollution can easily attach to the pulmonary epithelial, and then induce adverse lung injury[3]. Accumulating evidences has revealed that short- or long-term exposure to $\mathrm{PM}_{2.5}$ may increase the risk of various respiratory illness for human, including idiopathic pulmonary fibrosis (IPF)[4], 
asthma[5], and chronic obstructive pulmonary disease (COPD)[6]. Otherwise, patients with lung-diseases would be two or three times the risk of death than normal population[7]. Hence, World Health Organization cites $\mathrm{PM}_{2.5}$ pollution as fifth leading risk factor for mortality and economic loss. In China, ambient $\mathrm{PM}_{2.5}$ was responsible for 1.2 million premature death as the forth healthy risk factor[8, 9]. From the public health view of point, it was imperative to comprehensively elucidate the causal relationship between $\mathrm{PM}_{2.5}$ pollution and lung injury.

There have been several publications about the adverse effects of $\mathrm{PM}_{2.5}$ to respiratory system using mice as model animal with oropharyngeal aspiration (OPA) or intranasal administration. Balb/c mice exposed to $\mathrm{PM}_{2.5}$ (2.5-20 $\mu \mathrm{g}$ for each mice) through OPA for 21 days showed obvious collagen deposition around small airway[10].Acute OPA of $\mathrm{PM}_{2.5}$ extract to mice may induce greater lung neutrophilia and inflammation[11]. C57BL/6 mice exposed to $\mathrm{PM}_{2.5}(3 \mathrm{mg} / \mathrm{kg})$ by OPA can adversely affect prenatal lung development in the offspring[12]. C57BL/6J mice showed significant inflammation and incipient fibrosis symptom after directly intranasal administration with $\mathrm{PM}_{2.5}(100 \mu \mathrm{g} /$ day $)$ for 4 weeks[13]. The obvious fibrous cap thickness observed from apoe-/- mice exposed to $\mathrm{PM}_{2.5}$ by intranasal instillation[14]. Generally, direct administration by $\mathrm{PM}_{2.5}$ suspension may under- or overestimate the healthy risk. There were only few investigations about the wholebody inhalational exposure. Yuan et al. (2020) found that C57BL/6 mice whole-body exposed to PM 2.5 $\left(59.77 \mu \mathrm{g} / \mathrm{m}^{3}\right)$ sampled from Beijing, China exhibited severe lung injury and fibrosis[11]. They also demonstrated that treatment with local $\mathrm{PM}_{2.5}$ polluted air at Beijing, China would strikingly induce lung oxidative stress and injury in mice for 3 weeks and 6 months, respectively[15, 16]. Zhou et al. (2019) exposed C57BL/6 mice to $\mathrm{PM}_{2.5}$ collected from Shijiazhuang, China, and found that significant increase in circulating white blood cells and inflammation in lungs of mice from exposure groups[17]. All the investigations were preformed to estimate the adverse effects on lung by $\mathrm{PM}_{2.5}$ in Beijing-Tianjin-Hebei region, China. The underlying mechanism have not been comprehensively elucidated.

Evidences have unveiled that air pollution was much more serious in economically developing levels cities than the economically developed mega-cities in China[18-20]. However, the assessment on the healthy risk of $\mathrm{PM}_{2.5}$ pollution in this mid-scale cities was scarce. An increase of $10 \mu \mathrm{g} / \mathrm{m}^{3} \mathrm{PM}_{2.5}$ was associated with 15-27\% increase in lung cancer mortality[21]. Moreover, the annual mean concentration of $\mathrm{PM}_{2.5}$ in mid-scale cities in China was marked higher than the limitation suggested by WHO as $10 \mu \mathrm{g} / \mathrm{m}^{3}[19,22]$. Hence, its warranted to investigate the consequences posed by $\mathrm{PM}_{2.5}$ in this region to pulmonary system using "real-world" exposure system.

High-throughput sequencing is a precise method to measure global gene expression profiles by RNAsequencing including mRNA and microRNA. Recently, this tool has been used to illuminate the associated molecular mechanism of cytotoxicity induced by $\mathrm{PM}_{2.5}[23,24]$. There was only one publication about the potential mechanism of lung injury posed by airborne $\mathrm{PM}_{2.5}$ at Beijing, China using transcriptome analysis[25]. Meanwhile, some evidences suggested that microRNA deregulation was likely to be associated with the respiratory diseased induced by $\mathrm{PM}[26,27]$. Hence, the integrated analysis between mRNA and microRNA to elucidate the underlying mechanisms of the lung injury posed by $\mathrm{PM}_{2.5}$ was imperative. 
In summary, we for the first time established a whole-body exposure system to investigate the adverse effects posed by $\mathrm{PM}_{2.5}$ sampled from Baoji $\left(33.35^{\circ}-35.06^{\circ} \mathrm{N}, 106.18^{\circ}-108.03^{\circ} \mathrm{E}\right)$, an inland city located in the mid-west part of China, using mice for 40 days. The objectives are to evaluate: (1) histopathological changes of lung tissue; (2) morphological changes of lung; (3) underlying mechanisms using mRNA-seq, microRNA-seq, and immunohistochemical analysis; (4) the potential biomarkers to lung injury posed by $\mathrm{PM}_{2.5}$; (4) the dominant components in $\mathrm{PM}_{2.5}$ associated with lung injury.

\section{Results}

\section{The contents of PAHs}

Seventeen US. EPA priority PAHs were detected with the sum concentrations of $570.48 \pm 143.82 \mathrm{ng} / \mathrm{m}^{3}$. As showed in Figure. S3, 5-ring PAHs accounted for $42 \%$ of the total. Benzo(b/k) fluoranthene (BbkF) was the most abundant PAH with concentration at $140.00 \pm 21.97 \mathrm{ng} / \mathrm{m}^{3}$, followed by benzo(a)pyrene (BaP) $(57.50 \pm$ $\left.10.37 \mathrm{ng} / \mathrm{m}^{3}\right)$, and dibenzo(a,e)pyrene (DBP) $\left(52.67 \pm 9.29 \mathrm{ng} / \mathrm{m}^{3}\right)$. The molecular distributions were consistent to the previous reports for the samples from Baoji, China[18].

\section{$\mathrm{PM}_{2.5}$-induced lung injury in mice}

Micro-CT were performed to determine the potential effect on the lung morphology induced by $\mathrm{PM}_{2.5}$ in vivo after the exposure before the histopathology assay. The tomograms showed higher density and confluent opacity of the mice lung tissues from exposure groups (Figure. $1 \mathrm{~d}$ and e), indicating the remarkable pulmonary inflammation induced by $\mathrm{PM}_{2.5}$, while no morphological changes were observed in the control (Figure. 1a and b). Moreover, we created the 3D reconstruction of the lung tissue of the mice to estimate the pulmonary function injury posed by $\mathrm{PM}_{2.5}$. As shown in Figure.1c and $\mathrm{f}$, the effective pulmonary function from exposure group markedly shrunk compared to the control group. The same results about the higher lung density and deteriorated PF were found by previous publication through intranasally administrating $[10,13,28]$. However, the adverse effects found in this work were much more obvious than the previous results, while the exposure concentration $\left(289.52 \mu \mathrm{g} / \mathrm{m}^{3}\right)$ was much lower that it (equal to $400-1543 \mu \mathrm{g} / \mathrm{m}^{3}$ ) in the previous work[10, 13], indicating exposure way may markedly impact the assessment on the toxicity of $\mathrm{PM}_{2.5}$ on the respiratory system. Meanwhile, the $\mathrm{PM}_{2.5}$ particles used previously were obtained from Shanghai, China, one of the megacities located in Yangtze River Delta, which suggested that the hazard level of the $\mathrm{PM}_{2.5}$ collected from the developing area in this work may be higher than the developed city.

As shown in Figure. 2, obvious alveolar intervals thicken, inflammatory cell infiltration, and alveolar structure damage (Figure. $2 b, e, h$ ) were observed from the pulmonary alveoli from exposure group compared with the vacuolated thin-walled of alveolar cavity as the intact structure shown in the control (Figure. 2a, d, g). The marked bronchiolar epithelial hyperplasia and endoluminal inflammatory cells infiltration were shown in the lung of $\mathrm{PM}_{2.5}$-treated mice (Figure. 2c, $\mathrm{f}, \mathrm{i}$ ), while simple ciliated columnar epithelium of bronchia in lung was characterized as normal pulmonary structure observed in control mice (Figure. 2a, d, g). The results found in this work were consistent to the previous investigations $[15,17,27,29]$. Noted that the pulmonary histopathological injury was irreversible, the long-term exposure to $\mathrm{PM}_{2.5}$ may pose severe threat on the 
respiratory system to human beings since the pollution is persistent. Since the prevalence of pulmonary fibrosis $(\mathrm{PF})$, a critical lung interstitial disease, was significantly associated with long-term exposure to $\mathrm{PM}_{2.5}[1]$, we determined lung fibrosis in mice from control and exposure groups using Masson trichrome stain. Obvious lung fibrosis increase was observed from exposure group (Figure. 2k) compared with the control (Figure. 2j), and the statistical results showed 2.56 -fold $(p<0.05)$ increase between the exposure and control group (Figure. $2 \mathrm{l}$ ).

To further elucidate the immune response activated through $\mathrm{PM}_{2.5}$ exposure in mice respiratory system, the relative abundances of leucocytes CD45+, as well as the epithelial cells (CD45-/CD31-/CD326+) in lung tissue of mice were determined using flow cytometry analysis. As shown in Figure. 3 , the relative abundance of leucocytes in exposure group were significantly higher than it in the control (Figure. 3a-c). However, there was no statistical difference of the epithelial cell abundances between the $\mathrm{PM}_{2.5}$-treated and control groups (Figure. $3 \mathrm{~d}-\mathrm{f})$. The results indicated that immune system response may be the dominate mechanism for the effects by $\mathrm{PM}_{2.5}$, which was parallel to previous works[30, 31]. However, the bronchiolar epithelial hyperplasia cannot be manifested using the relative abundance of the cells, which may ascribe to the interference of the overwhelming quantity advantage of the leucocytes. Further experiments (e.g., single-cell sequencing) will be performed to elucidate the underlying mechanism of the difference occurred in epithelial cells.

\section{$\mathrm{PM}_{2.5}$-induced changes of gene expression profile in mice lung}

To investigate the underlying molecular mechanism of the lung injury posed by $\mathrm{PM}_{2.5}$, RNA-sequencing was performed to analyze the whole-genome expression profiling changes of the mice lung tissues with or without exposed to $\mathrm{PM}_{2.5}$. As shown in the Figure. S4, there was 1607 DEGs (1159 up-regulation and 448 downregulation) identified in comparison of control and exposure groups (Volcano Plot). The top 8 up-regulated KEGG enriched pathway including B cell receptor signaling pathway, p53 signaling pathway, and T cell receptor signaling pathway, and the top 10 down-regulated KEGG enrichment including cell adhesion molecules (CAMs), calcium signaling pathway, and malaria were characterized (Table S3), which was parallel to the previous study about the mice exposed to $\mathrm{PM}_{2.5}$ collected from Beijing, China[25]. Meanwhile, the top 10 up- and downregulated genes were listed in Table $\mathrm{S4}$.

\section{$\mathrm{PM}_{2.5}$-induced changes of microRNA expression profile in mice lung}

According to the microRNA-sequencing analysis, a total of 70 microRNA (53 up-regulation and 17 downregulation) were identified in comparison of control and exposure groups, and the fold changes were shown in Figure. S5. As shown in Table S5, the top 20 KEGG pathway enrichment determined by KEGG annotation including GnRH signaling pathway, HIF-1 signaling pathway, and MAPK signaling pathway were identified. The similar results of the KEGG pathway (i.e., HIF-1 signaling pathway, Insulin signaling pathway, and MAPK signaling pathway) were found by previous investigation about the $\mathrm{PM}_{2.5}$ collected from Shijiazhuang, Hebei, China using microRNA microarray analysis[27]. The top 10 up- and down-regulated microRNA were listed in Table S6.

\section{Integrated analysis between the gene expression and microRNA}


To further elucidate the molecular mechanisms, the integrated analysis of mRNA and microRNA expression data were performed. A total of 3024 mRNA (1625 up-regulated and 1399 down-regulated) and 100 microRNA (59 up-regulated and 41 down-regulated) were identified in comparison of control and exposure groups (Figure. S6a). The KEGG pathway (top 20) involved into inflammation and immune pathways, including cell adhesion molecules (CAMs) $(p=0.0068), B$ cell receptor signaling pathway $(p=0.019)$, primary immunodeficiency $(p=$ 0.078), were significantly enriched (Figure. S6b and Table S7), which was consistent to the KEGG annotations associated with mRNA expression levels, but was robuster through integrated analysis. GO annotations found that the biology process (BP) including immune system process, regulation of biological quality, and regulation of immune system process were significantly enriched (Figure. S6c).

To further validate the causal relationship between the enriched KEGG pathway and the lung injury posed by $\mathrm{PM}_{2.5}$. Nine representative pathways involved into the immune system, including B cell receptor signaling pathway, cell adhesion molecules (CAMs), antigen processing and presentation, were chosen (Figure. 4a). The input genes associated with the enriched KEGG pathway annotated by integrated analysis were showed in Table S7. As showed in Figure. 4b, we selected 27 genes to explore the mechanism for the pathway in $\mathrm{PM}_{2.5^{-}}$ exposed lung tissue. Among these genes (showed in Table 1), Cd72, Cd81, Cd19, Pik3cd, and Ppp3cc were involved into B cell receptor signaling pathway, while $\mathrm{Cd} 8 \mathrm{O}, \mathrm{Cd} 22, \mathrm{H} 2-\mathrm{M} 2, \mathrm{H2}-\mathrm{T} 24$, and $\mathrm{H2}$-T3 were involved into cell adhesion molecules (CAMs). Tapbp and KIrc1, Prf1, and Jak3 and Tnfrsf13c were involved into antigen processing and presentation, graft-versus-host disease, and primary immunodeficiency, respectively. Angpt2, Pdgfra, P2ry1, and Igfl were associated with Rap1 signaling pathway. Ptpn 7 and Fgf22 were related to MAPK signaling pathway. Rasal1 and Lamc1 were involved into Ras signaling pathway and small cell lung cancer, respectively. Gene Met, Ralgds, and Cd8b1 were identified involved into multiple pathways. The associated microRNAs (total of 30 ) were mapped in Figure.4b and Table 1. 
Table 1

Selected genes and microRNAs expression changes validated by RT-qPCR.

\begin{tabular}{|c|c|c|c|c|c|c|}
\hline KEGG pathway & mRNA & $\begin{array}{l}\text { Q-RT- } \\
\text { PCR }\end{array}$ & Transcriptomics & microRNA & $\begin{array}{l}\text { RT- } \\
\text { qPCR }\end{array}$ & Transcriptomics \\
\hline \multirow[t]{7}{*}{$\begin{array}{l}\text { B cell receptor } \\
\text { signaling pathway }\end{array}$} & \multirow[t]{2}{*}{ Cd72 } & \multirow[t]{2}{*}{$\begin{array}{l}2.50 \pm \\
0.19\end{array}$} & \multirow[t]{2}{*}{$2.44 \pm 0.28$} & $149-5 p$ & $\begin{array}{l}0.78 \\
\pm \\
0.017\end{array}$ & $0.50 \pm 0.033$ \\
\hline & & & & $328-3 p$ & $\begin{array}{l}0.85 \\
\pm 0.10\end{array}$ & $0.57 \pm 0.054$ \\
\hline & Cd81 & $\begin{array}{l}0.36 \pm \\
0.032\end{array}$ & $0.39 \pm 0.024$ & $24-3 p$ & $\begin{array}{l}0.89 \\
\pm \\
0.078\end{array}$ & $0.59 \pm 0.063$ \\
\hline & Cd19 & $\begin{array}{l}4.87 \pm \\
0.26\end{array}$ & $2.87 \pm 0.33$ & $466 i-5 p$ & $\begin{array}{l}0.84 \\
\pm 0.16\end{array}$ & $0.40 \pm 0.081$ \\
\hline & \multirow[t]{2}{*}{ Pik3cd } & \multirow[t]{2}{*}{$\begin{array}{l}2.03 \pm \\
0.13\end{array}$} & \multirow[t]{2}{*}{$1.65 \pm 0.18$} & $203-5 p$ & $\begin{array}{l}1.22 \\
\pm 0.15\end{array}$ & $2.79 \pm 1.01$ \\
\hline & & & & $7 a-5 p$ & $\begin{array}{l}1.58 \\
\pm 0.23\end{array}$ & $2.15 \pm 0.93$ \\
\hline & Рpp3cc & $\begin{array}{l}1.63 \pm \\
0.47\end{array}$ & $1.66 \pm 0.21$ & $92 a-1-5 p$ & $\begin{array}{l}1.52 \\
\pm 0.32\end{array}$ & $2.93 \pm 1.33$ \\
\hline \multirow[t]{6}{*}{$\begin{array}{l}\text { Cell adhesion } \\
\text { molecules (CAMs) }\end{array}$} & \multirow[t]{2}{*}{ Cd80 } & \multirow[t]{2}{*}{$\begin{array}{l}1.68 \pm \\
0.13\end{array}$} & \multirow[t]{2}{*}{$5.26 \pm 0.65$} & $674-3 p$ & $\begin{array}{l}0.86 \\
\pm \\
0.086\end{array}$ & $0.61 \pm 0.038$ \\
\hline & & & & $1247-5 p$ & $\begin{array}{l}0.48 \\
\pm \\
0.055\end{array}$ & $0.17 \pm 0.011$ \\
\hline & $\mathrm{Cd} 22$ & $\begin{array}{l}2.18 \pm \\
0.16\end{array}$ & $3.74 \pm 0.59$ & $3110-5 p$ & $\begin{array}{l}1.97 \\
\pm 0.88\end{array}$ & $10.17 \pm 1.81$ \\
\hline & $H 2-M 2$ & $\begin{array}{l}514.25 \\
\pm 0.36\end{array}$ & $17.37 \pm 0.44$ & & & \\
\hline & H2-T24 & $\begin{array}{l}0.64 \pm \\
0.036\end{array}$ & $0.30 \pm 0.032$ & & & \\
\hline & H2-T3 & $\begin{array}{l}1.51 \pm \\
0.059\end{array}$ & $3.96 \pm 0.54$ & $486 a-3 p$ & $\begin{array}{l}0.62 \\
\pm 0.11\end{array}$ & $0.57 \pm 0.033$ \\
\hline \multirow[t]{2}{*}{$\begin{array}{l}\text { Antigen processing } \\
\text { and presentation }\end{array}$} & tapbp & $\begin{array}{l}0.41 \pm \\
0.070\end{array}$ & $0.42 \pm 0.051$ & & & \\
\hline & Klrc1 & $\begin{array}{l}0.93 \pm \\
0.034\end{array}$ & $0.19 \pm 0.011$ & $1981-5 p$ & $\begin{array}{l}0.029 \\
\pm \\
0.011\end{array}$ & $0.49 \pm 0.054$ \\
\hline $\begin{array}{l}\text { Graft-versus-host } \\
\text { disease }\end{array}$ & Prf1 & $\begin{array}{l}0.46 \pm \\
0.077\end{array}$ & $0.12 \pm 0.021$ & & & \\
\hline
\end{tabular}

B-Actin and GAPDH were the endogenous control for gene, U6 was the endogenous control for microRNA. 


\begin{tabular}{|c|c|c|c|c|c|c|}
\hline KEGG pathway & mRNA & $\begin{array}{l}\text { Q-RT- } \\
\text { PCR }\end{array}$ & Transcriptomics & microRNA & $\begin{array}{l}\text { RT- } \\
\text { qPCR }\end{array}$ & Transcriptomics \\
\hline \multirow[t]{3}{*}{$\begin{array}{l}\text { Primary } \\
\text { immunodeficiency }\end{array}$} & \multirow[t]{2}{*}{ Jak3 } & \multirow[t]{2}{*}{$\begin{array}{l}3.50 \pm \\
0.23\end{array}$} & \multirow[t]{2}{*}{$2.14 \pm 0.19$} & $3074-5 p$ & $\begin{array}{l}0.75 \\
\pm 0.14\end{array}$ & $0.59 \pm 0.061$ \\
\hline & & & & $351-3 p$ & $\begin{array}{l}0.85 \\
\pm 0.14\end{array}$ & $0.13 \pm 0.012$ \\
\hline & Tnfrsf13c & $\begin{array}{l}2.02 \pm \\
0.38\end{array}$ & $5.03 \pm 0.66$ & $676-3 p$ & $\begin{array}{l}0.57 \\
\pm 0.11\end{array}$ & $0.51 \pm 0.031$ \\
\hline \multirow[t]{6}{*}{$\begin{array}{l}\text { Rap1 signaling } \\
\text { pathway }\end{array}$} & Angpt2 & $\begin{array}{l}0.39 \pm \\
0.042\end{array}$ & $0.47 \pm 0.022$ & & & \\
\hline & \multirow[t]{3}{*}{ Pdgfra } & \multirow[t]{3}{*}{$\begin{array}{l}0.39 \pm \\
0.018\end{array}$} & \multirow[t]{3}{*}{$0.50 \pm 0.035$} & $222-3 p$ & $\begin{array}{l}0.69 \\
\pm \\
0.094\end{array}$ & $0.61 \pm 0.050$ \\
\hline & & & & $15 a-5 p$ & $\begin{array}{l}1.09 \\
\pm 0.29\end{array}$ & $1.73 \pm 0.32$ \\
\hline & & & & $344-3 p$ & $\begin{array}{l}1.63 \\
\pm 0.38\end{array}$ & $2.09 \pm 0.41$ \\
\hline & P2ry 1 & $\begin{array}{l}0.45 \pm \\
0.029\end{array}$ & $0.32 \pm 0.015$ & $205-5 p$ & $\begin{array}{l}1.40 \\
\pm 0.59\end{array}$ & $3.74 \pm 1.11$ \\
\hline & lgf1 & $\begin{array}{l}1.78 \pm \\
0.16\end{array}$ & $4.86 \pm 0.98$ & & & \\
\hline \multirow[t]{2}{*}{$\begin{array}{l}\text { MAPK signaling } \\
\text { pathway }\end{array}$} & Ptpn7 & $\begin{array}{l}1.68 \pm \\
0.18\end{array}$ & $5.42 \pm 0.88$ & & & \\
\hline & Fgf22 & $\begin{array}{l}1.53 \pm \\
0.16\end{array}$ & - & & & \\
\hline \multirow[t]{2}{*}{$\begin{array}{l}\text { Ras signaling } \\
\text { pathway }\end{array}$} & \multirow[t]{2}{*}{ Rasal1 } & \multirow[t]{2}{*}{$\begin{array}{l}1.75 \pm \\
0.14\end{array}$} & \multirow[t]{2}{*}{$10.03 \pm 1.33$} & $27 a-3 p$ & $\begin{array}{l}0.75 \\
\pm \\
0.050\end{array}$ & $0.58 \pm 0.044$ \\
\hline & & & & $329-5 p$ & $\begin{array}{l}1.31 \\
\pm 0.15\end{array}$ & $2.96 \pm 1.32$ \\
\hline \multirow[t]{2}{*}{$\begin{array}{l}\text { Small cell lung } \\
\text { cancer }\end{array}$} & \multirow[t]{2}{*}{ Lamc1 } & \multirow[t]{2}{*}{$\begin{array}{l}0.35 \pm \\
0.027\end{array}$} & \multirow[t]{2}{*}{$0.42 \pm 0.051$} & $138-5 p$ & $\begin{array}{l}1.23 \\
\pm 0.17\end{array}$ & $3.76 \pm 1.85$ \\
\hline & & & & $211-5 p$ & $\begin{array}{l}1.16 \\
\pm 0.19\end{array}$ & $8.83 \pm 1.93$ \\
\hline $\begin{array}{l}\text { PI3K-Akt signaling } \\
\text { pathway }\end{array}$ & Rxra & $\begin{array}{l}0.58 \pm \\
0.057\end{array}$ & $0.64 \pm 0.041$ & $486 b-3 p$ & $\begin{array}{l}0.47 \\
\pm 0.18\end{array}$ & $0.57 \pm 0.046$ \\
\hline $\begin{array}{l}\text { Rap1 signaling } \\
\text { pathway/MAPK } \\
\text { signaling } \\
\text { pathway/Ras } \\
\text { signaling } \\
\text { pathway/PI3K-Akt } \\
\text { signaling pathway }\end{array}$ & Met & $\begin{array}{l}0.56 \pm \\
0.037\end{array}$ & $0.34 \pm 0.029$ & $449 a-5 p$ & $\begin{array}{l}2.92 \\
\pm 0.64\end{array}$ & $5.10 \pm 1.87$ \\
\hline B-Actin and GAPDH & & & & & & \\
\hline
\end{tabular}




\begin{tabular}{|c|c|c|c|c|c|c|}
\hline KEGG pathway & mRNA & $\begin{array}{l}\text { Q-RT- } \\
\text { PCR }\end{array}$ & Transcriptomics & microRNA & $\begin{array}{l}\text { RT- } \\
\text { qPCR }\end{array}$ & Transcriptomics \\
\hline & & & & $143-5 p$ & $\begin{array}{l}0.87 \\
\pm 0.19\end{array}$ & $0.55 \pm 0.029$ \\
\hline \multirow{3}{*}{$\begin{array}{l}\text { Rap1 signaling } \\
\text { pathway/Ras } \\
\text { signaling pathway }\end{array}$} & Ralgds & $\begin{array}{l}1.35 \pm \\
0.14\end{array}$ & $1.65 \pm 0.24$ & 6538 & $\begin{array}{l}0.89 \\
\pm 0.24\end{array}$ & \\
\hline & & & & $449 c-5 p$ & $\begin{array}{l}1.50 \\
\pm 0.37\end{array}$ & $7.82 \pm 1.88$ \\
\hline & & & & $3074-2-3 p$ & $\begin{array}{l}0.86 \\
\pm 0.17\end{array}$ & $0.48 \pm 0.033$ \\
\hline $\begin{array}{l}\text { Cell adhesion } \\
\text { molecules } \\
\text { (CAMs)/Antigen } \\
\text { processing and } \\
\text { presentation/Primary } \\
\text { immunodeficiency }\end{array}$ & $C d 8 b 1$ & $\begin{array}{l}1.40 \pm \\
0.38\end{array}$ & $3.55 \pm 0.38$ & & & \\
\hline
\end{tabular}

The RT-qPCR analysis was performed to validate the results from transcriptomics. As showed in Table 1, most of the genes and microRNAs we selected showed similar results to those of the transcriptomics. Gene $C d 72$, Cd19, Pik3cd involved into B cell receptor signaling pathway were significantly up-regulated from exposure group, while gene $C d 81$ was markedly down-regulated (Figure. 4c). The mRNA transcript levels of gene $C d 22$ and $H 2-M 2$ related to CAMs strikingly increased, and the levels of H2-T24 decreased markedly (Figure. 4c). In addition, the associated microRNA involved into $B$ cell receptor signaling pathway including 203-5p, 7a-5p, and 92a-1-5p were significantly up-regulated in $\mathrm{PM}_{2.5}$-exposed group. The obvious down-regulations of microRNA 149-5p, 328-3p, 466i-5p, and 24-3p were observed in exposure group (Figure. 4d). Among the CAMs, we found that the microRNA 674-3p, 486a-3p, and 1247-5p increased remarkably, while 486a-3p was significantly downregulated in exposure group (Figure. 4d).

The protein expression of CD19, CD81, and PIK3CD involved into the B cell receptor signaling pathway was examined to confirm the changes of the associated genes by immunohistochemistry. As showed in Figure. 5, $\mathrm{PM}_{2.5}$ exposure significantly increased CD19 (Figure. 5b), CD81 (Figure. 5e), and PIK3CD (Figure. 5h) expression levels compared with the control (Figure. $5 \mathrm{a}, \mathrm{d}, \mathrm{g}$ ). Semiquantitative analysis showed that the fold changes of the expression of CD19, CD81, and PIK3CD from PM 2.5 -exposure group were 6.948-, 2.646-, and 2.724- compared with the expression in the control, respectively (Figure. $5 c, f, i, p<0.05$ ).

\section{Discussion}

Some evidences have suggested that the adverse effects on lung tissue posed by $\mathrm{PM}_{2.5}$ maybe associated with the immune and inflammatory response[11, 15, 32]. Hence, B cell receptor signaling pathway, as the important pathway responsible for immune response[33], enriched by integrated analysis was foreseeable, which was also illuminated by previous study using RNA-sequencing[25]. The transcriptional levels of the target genes involved in this pathway were also significantly up- or down-regulated by $\mathrm{PM}_{2.5}$. Among them, $C d 72$, type II 
transmembrane protein coding gene belonging to C-type lectin family[34], was elucidated play an important role in controlling the magnitude of $B$ cell responses[35], and then responsible for the immune system homeostasis regulation[36]. The overexpression of $C d 72$ found in this work from $\mathrm{PM}_{2.5}$-exposed group may promote $B$ cell survival and proliferation, and enhance release of $C D 23$, and then activate the immune response[37-39]. In addition, anti-CD72 monoclonal antibodies (mAbs) can activate CD19 tyrosine phosphorylation[40]. The similar result was observed in this work (the up-regulation of $C d 19$ induced by $\mathrm{PM}_{2.5}$ ). It was reported that mutation of gene pik3cd was associated with the prevalence of systemic lupus erythematosus, which is a typical immune system disease[41]. Hence, the marked increase of the mRNA level of pik3cd in lung tissue from exposure group might related to the immune response induced by $\mathrm{PM}_{2.5}$. Meanwhile, the associate microRNA of $C d 72149-5 p$ and 328-3p were significantly down-regulated by $\mathrm{PM}_{2.5}$. It has reported that the two microRNA may be responsible for the lung inflammatory and fibrotic pathology in mice[42]. The microRNA (203-5p and 7a-5p) related to Pik3cd were markedly up-regulated in mice lung from exposure group. Based on the KEGG and GO annotations, the microRNA 203-5p was involved into the B cell receptor signaling pathway (Figure. S7a). Therefore, the increase of the expression levels of gene $C d 72, C d 19$, and Pik3cd involved into B cell receptor signaling pathway may contribute to the lung injury including inflammation and fibrosis induced by $\mathrm{PM}_{2.5}$.

Surprisingly, we firstly found the most significantly enriched KEGG pathway of DEGs through integrated analysis was cell adhesion molecules (CAMs), which was identified to mediate the process of cell recruitment and homing, and play an important role in the inflammatory process[43]. Once the inflammatory process of pulmonary immune system was triggered by $\mathrm{PM}_{2.5}$, the up-regulation of adhesion molecules genes occurred in endothelial and immune cells to mediate leukocyte adhesion and then migrating to inflammation sites[44]. From the results of RT-qPCR quantification and transcriptomics analysis, the significant upswing of the expression levels of genes $\mathrm{Cd} 22$ and $\mathrm{H} 2-\mathrm{M} 2$ were observed from $\mathrm{PM}_{2.5}$-treated group. The gene $\mathrm{Cd} 22$, a immunoglobulin superfamily cell-surface molecule that serves as an adhesion receptor for sialic acid-bearing ligands[45], was elucidated to active B cells and regulate antigen receptor signaling in vitro[46]. Similarly, the associated microRNA $3110-5 p$ for $\mathrm{Cd} 22$ were significantly stimulated from exposure group. Thus, our finding indicated that CAMs may be a key pathway responsible for the adverse effects posed by $\mathrm{PM}_{2.5}$ to respiratory system. According to the KEGG and GO annotations (Figure. S7b), the genes $C d 22$ and H2-M2 can be used as feasible biomarkers.

Furthermore, the target genes involved in the insignificant $(P>0.05)$ enriched KEGG pathways (i.e., antigen processing and presentation, graft-versus-host disease, primary immunodeficiency, rap1 signaling pathway, MAPK signaling pathway, ras signaling pathway, small cell lung cancer, and PI3K-Akt signaling pathway) were also significantly up- or down-regulated by $\mathrm{PM}_{2.5}$, suggesting these pathways related to immune response of lung tissue should also be concerned for the further investigation.

A number of investigations have demonstrated that long-term exposure to PAHs increased risk of developing lung cancer[47-49]. CCA was performed using concentrations of PAHs as environmental factor. As showed in Figure. S8, the top three PAHs canonically correlated to target genes and microRNA were BaP, DBP, DBA, and $\mathrm{BaP}, \mathrm{DBP}$, benzo[b]fluorene (BF), respectively, indicating the four PAHs not the one with top concentration maybe the main impact factors. Among them, $\mathrm{BaP}$ was traditionally used as the surrogate marker for the toxicity of 
PAHs mixtures[50]. DBP has been evaluated 100 times carcinogenic potency than BaP[50]. The potency value of dibenzo[a, h]anthracene (DBA), which was estimated to be associated with human cancer[51], was reported to be up to 10 times than Bap[52]. To further explore the covariation between the PAHs and genetic indicators, Pearson's index was determined. Obvious covariable relationship was observed between the target genes including Cd72, Cd19, Pik3cd, Cd22, H2-M24, and associated microRNA, and the PAHs detected from PM 2.5 (Figure. S9, p < 0.05). This result suggested the target genetic indicators we selected showed a significant covariation with environmental pollutants, and then they may be used as the biomarkers to indicate the healthy risk posed by these types of pollutants.

From the public health point of view, $\mathrm{PM}_{2.5}$ samples used in this work were collected from Baoji, the mid-scale city located at the developing area. The main components of PAHs detected from the $\mathrm{PM}_{2.5}$ were similar to the mega-city (e.g., Beijing, Nanjing, et.al), while the concentrations of them, especially for Bap, DBA, DBP were statistically higher than the developed area[53-55]. Noted the concentrations of $\mathrm{PM}_{2.5}$ in all regions in China were very high than the threshold proposed by WHO $(35 \mu \mathrm{g} / \mathrm{mL})$ or more permissive limits adopted by China $(75 \mu \mathrm{g} / \mathrm{mL})$ in spite of the general decrease trends observed recent years[56]. Meanwhile, energy structure was much different between the mid-scale city and the mega-city in China[57], which directly result in the variation of the occurrence levels of the organic pollutants (PAHs) derived from the fossil fuel combustion[58]. Combined with the obviously adverse effects of the $\mathrm{PM}_{2.5}$ collected from Baoji city on the respiratory system found in this work, the healthy risk posed by $\mathrm{PM}_{2.5}$ at the mid-scale city of China should be paid more attention.

\section{Conclusion}

This work for the first time estimated the lung injury posed by $\mathrm{PM}_{2.5}$ collected from Baoji, a representative midscale city of China. We also elucidated the underlying mechanisms through integratedly analyzing the profiles of mRNA-seq and microRNA-sEq. Obvious lung injuries including pulmonary dysfunction, inflammatory response, pulmonary fibrosis were observed in the lung tissues of mice from exposure group. As revealed by KEGG annotations, the main pathway induced by $\mathrm{PM}_{2.5}$ was immune system associated pathway, especially $B$ cell receptor signaling pathway and cell adhesion molecules (CAMs). Moreover, the expression levels of the key genes and microRNAs involved into the pathway, as well as the associated protein expression were verified. The results from this work may provide deeper insight into the mechanisms for the pulmonary toxicity posed by $\mathrm{PM}_{2.5}$ in the developing area. The more adverse effects on lung tissue posed by $\mathrm{PM}_{2.5}$ from mid-scale city of China than it from the mega city suggested the potential health risk of $\mathrm{PM}_{2.5}$ in developing area should be more concerned.

\section{Methods}

\section{$\mathrm{PM}_{2.5}$ particle collection and analysis}

Ambient $\mathrm{PM}_{2.5}$ were collected on quartz filter (2 $\mu \mathrm{m}$ pore size) by a High-Volume Ultrafine Particle Sampler (Ju Kang Technology, China) at a $5 \mathrm{~L} / \mathrm{min}$ flow rate from Baoji, shaanxi, China, maintained for $24 \mathrm{~h}$. $\mathrm{PM}_{2.5} \mathrm{Was}$ extracted described previously[59]. Briefly, the filters were chopped into small fragments, and then shaken for $20 \mathrm{~min}$ after treated by ultrasonic in ice for $30 \mathrm{~min}$ in a $50-\mathrm{mL}$ centrifuge tube. The process was repeated for 
three times. The mixture was centrifuged at $8000 \mathrm{rpm}$ for $10 \mathrm{~min}$, and then the precipitate was transplanted into a new tube and dried by lyophilization. The powder was stored at $-80{ }^{\circ} \mathrm{C}$ until experiment. The concentrations of seventeen EPA priority polycyclic aromatic hydrocarbons (PAHs) bonding on the $\mathrm{PM}_{2.5}$ were determined by gas chromatography coupled with a mass spectrometer (GC-MS, Agilent GC 6890, MS 5973, USA) following the previous publication[60]. The details were shown in supporting information. Instrumental and method detection limits were showed in Table S1.

\section{Animals and whole-body inhalation}

Male Balb/C mice at 8 weeks of age with body mass of $20 \pm 2 \mathrm{~g}$ were purchased from Chengdu Dashuo Company (Chengdu, Sichuan, China) and acclimated for a week before exposure in SPF level animal house of West China Hospital. Subsequently, twenty mice were divided randomly into two groups ( $n=10$ for each group) exposed to either filtered air (control) or concentrated $\mathrm{PM}_{2.5}$ air (exposure) in a "real-world" exposure system for 8 h/day (9:00 a.m. to 17:00 p.m.), 6 days/week, for 8 weeks (November 25st, 2019 to January 20th, 2020). The exposure system comprises two chambers: (1) ambient air was inhaled into the chamber filtered by a Teflon

filter to eliminate all the fine particles as the control group; (2) the concentrated $\mathrm{PM}_{2.5}$ regenerated using a aerosol generator (HRH-7886, Beijing Huironghe Technology Co., Ltd., China) was inhaled into the chamber filtered by a swirler to remove the PM with an aerodynamic diameter greater than $2.5 \mu \mathrm{M}$ as the exposure group. The exposure schematic was showed in Figure.S1.

During the exposure, the mice were fed commercial mouse chow and distilled water ad libitum, the humidity was kept at $40-60 \%$, and the temperature was controlled at $22 \pm 2{ }^{\circ} \mathrm{C}$ in the cages with $12 \mathrm{~h} / 12 \mathrm{~h}$ light-dark cycle. Meanwhile, the concentration of the $\mathrm{PM}_{2.5}$ was on-line monitored with a concentration monitor (DUSTTRAKTM II-Model 8530, TSI Instrument, Shoreview, MN). The $\mathrm{PM}_{2.5}$ concentrations were lower than detection level in control chamber, and $298.52 \pm 25.86 \mu \mathrm{g} / \mathrm{m}^{3}$ (the same magnitude with the $\mathrm{PM}_{2.5}$ levels in Baoji air) in exposure chamber, respectively. Animal studies were performed in accordance with the principles of laboratory animal care (NIH publication no. 85 - 23, revised 1985) and with approval by the Animal Ethical and Welfare Committee of West China Hospital (No. 2019272A). The experiment timeline was showed in Figure.S2. According to the criteria provided previously, the daily ventilation volume of adult male Balb/C mice is $0.0864 \mathrm{~m}^{3}[61]$. Previous investigation has revealed that $75 \%$ of $\mathrm{PM}_{2.5}$ particles would enter and touch alveoli through inhalation[62]. Hence, the daily exposure dose of $\mathrm{PM}_{2.5}$ for one mouse was: $298.52 \mu \mathrm{g} / \mathrm{m}^{3} \times 0.0864 \mathrm{~m}^{3}$ $\times 0.75=19.34 \mu \mathrm{g}$.

\section{Lung imaging}

After exposure, eight mice (each group 4 mice) were randomly selected and anesthetized with isoflurane for an in vivo lung micro-CT analysis. Images were obtained using Small-animal Micro-CT (Quantum GX, PerkinElmer). Parameters used for scanning were showed below: scanning field of view $50 \mathrm{~mm}$, voxel size $50 \mu \mathrm{m}$, scanning time: $4 \mathrm{~min}$. After reconstructed by NRecon software, the tomograms were analyzed by MicroCT/Small-animal imaging data analysis system (Analyze 12.0, PerkinElmer).

\section{Lung tissues preparation and histopathology assay}

After exposure, the mice were anesthetized by pentobarbital sodium. Blood samples were collected from the cardiac vein. Serum was obtained by centrifuged at $3000 \mathrm{rpm}$ for $15 \mathrm{~min}$ with no anticoagulant added to detect 
the routine blood indexes. The lung tissue of each mice was immediately separated. After washed by precooled phosphate buffered saline (PBS) for 3 times, the left lung tissues were divided into two parts. One part was used for flow cytometry analysis, and the other was fixed with $10 \%$ formaldehyde solution immediately and then embedded in paraffin. Paraffin-embedded tissues $\left(60^{\circ} \mathrm{C}\right)$ were sectioned consecutively with a thickness of $5 \mu \mathrm{m}$. The slices were then deparaffinized and stained with hematoxylin and eosin (H\&E) or Masson trichrome. More than five replicates per lung tissue each mouse were observed with an optical microscope to determine the histopathology from exposure group. The right lung tissues were kept at $-80^{\circ} \mathrm{C}$ for further analysis.

\section{Flow cytometry analysis}

The flow cytometry analysis was performed as previously described. Briefly, one part of the left lung tissues were minced on ice, and then digested by $0.1 \%$ Type I and Type $\triangle$ Collagenase in $4 \mathrm{ml}$ of the PBS system, in 37

${ }^{\circ} \mathrm{C}$ in the incubator, shaking incubation for $1 \mathrm{~h}$. After digestion completely, cell suspension was filtered through $50 \mu \mathrm{M}$ filter and centrifuged at $500 \mathrm{rpm}$ for $5 \mathrm{~min}, 4^{\circ} \mathrm{C}$. Cell pellets were resuspended by $100 \mu \mathrm{L}$ PBS and staining with $1 \mu \mathrm{L}$ Ms CD45 PE 30-F11 (BD Pharmingen), Ms CD326 APC G8.8 (BD Pharmingen), Alexa Fluor 488 anti-mouse CD31 (Biolegend) and incubated at $4{ }^{\circ} \mathrm{C}$ for $30 \mathrm{~min}$. Leucocytes were defined by CD $45+$ cells, and epithelial cells were defined by CD45-/CD31-/CD326 + cells. The measurements were performed by MoFlo Astrios EQ (BECKMAN COULTER). The percentage of different cells were analyzed by Flowjo_V10 Software.

\section{RNA extraction, sequencing and analysis}

Total RNA, including microRNA, was extracted from lung tissues by Trizol (Invitrogen, USA) according to manufacturer's protocol. RNA purity was checked using the NanoPhotometer ${ }^{\circledR}$ spectrophotometer (IMPLEN, CA, USA), integrity was assessed using the RNA Nano 6000 Assay Kit of the Agilent Bioanalyzer 2100 system (Agilent Technologies, CA, USA), and concentration was measured using Qubit ${ }^{\circledR}$ RNA Assay Kit in Qubit $\circledast 2.0$ Flurometer (Life Technologies, CA, USA). Library construction and mRNA and microRNA sequencing were performed on an Illumina Novaseq platform. The detailed protocols were showed in supporting information.

The paired-end RNA reads were aligned to the reference genome using Hisat2 v2.0.5 software. The gene expression level was quantified by feature Counts v1.5.0-p3. The microRNA reads were quality controlled using miRBase20.0 as reference, modified by software miredeep2. The potential microRNA secondary structures were obtained using srna-tools-cli. MicroRNA expression levels were estimated by TPM (transcript per million). Differential expressions of RNA and microRNA between exposure and control group were analyzed using the DESeq2 R package (1.16.1) and DESeq R package (1.8.3), respectively. The resulting P-values were adjusted using the Benjamini and Hochberg's approach for controlling the false discovery rate. Corrected $P$ value of 0.05 was set as the threshold for significantly differential expression by default.

The integrated mRNA and microRNA expression data were used to predict microRNA targets genes by Target Scan Mouse V 7.1 and miRDB V5 databases. According to the inhibition principle of microRNA on mRNA, the significantly down-regulated microRNA and significantly up-regulated mRNA, as well as the combination of significantly up-regulated microRNA and significantly down-regulated mRNA were selected as target gene pairs. Kyoto Encyclopedia of Genes and Genomes (KEGG) and Gene Ontology (GO) enrichment analysis of differently expressed genes was determined by clusterProfiler $R$ package. $P$ value less than 0.05 were considered as significant enrichment. 


\section{Quantitative real-time PCR analysis}

To verify the data from the transcriptomics, 27 genes and 29 microRNA were chosen as candidates for RT-qPCR analysis. Primer sequences were listed in Table S2. Glyceraldehyde 3-phosphate dehydrogenase (GAPDH) and $\beta$-actin genes were used as the endogenous control to monitor the quality of the target genes. MicroRNA U6 was used as the internal standard to monitor the quality of the target microRNA. The variations in the endogenous control expression were below $10 \%$ for all groups. Amplification was performed using SYBR Green PCR master mix (Applied Biosystems) according to the manufacturer's instructions. Gene and microRNA expressions were quantified using the $2^{-} \triangle \Delta$ Ct method suggested by Applied Biosystems (Foster City, CA, USA). The fold change between the exposure group and the control were calculated by the geometric mean of the relative expression normalized by the two housekeeping genes ( $\beta$-Actin and GAPDH)[63].

\section{Immunohistochemical analysis}

Immunohistochemistry was performed according to standard procedures involving monoclonal antibodies against CD19 (ab245235, Abcam), CD81 (sc-166029, Santa Cruz Biotechnologies), and PIK3CD (sc-55589, Santa Cruz Biotechnologies).

\section{Statistical analysis}

The statistical program SPSS 18.0 (Chicago, IL, USA) was used to analyze all the collected data. Five or more replicates of each parameter were determined to eliminate the variability of the results. All the data were expressed as mean \pm standard deviations (S.D). Two-tail student's T-test ( $95 \%$ confidence interval) was used to examine the significance of differences between control and exposure groups. Semiquantitative analysis on the results of Masson trichrome stain and immunohistochemistry was determined by Image-Pro Plus 6.0 software. The Pearson correlation test was performed for correlations between the biomarkers. Canonical correlation analysis (CCA) among the biomarkers were conducted using Canoco version 4.5. The statistic significant was defined as $p<0.05$.

\section{Abbreviations}

PM2.5

$\mathrm{PM}<2.5 \mu \mathrm{m}$ in diameter

PIK3CD

phosphatidylinositol-4,5-bisphosphate 3-kinase catalytic subunit delta

PAHs

polycyclic aromatic hydrocarbons

BaP

benzo(a)pyrene

\section{CAMs}

cell adhesion molecules; IPF, idiopathic pulmonary fibrosis

COPD

chronic obstructive pulmonary disease

OPA 
oropharyngeal aspiration

PBS

phosphate buffered saline

HE

hematoxylin and eosin

PCR

Polymerase Chain Reaction

RT-qPCR

Quantitative real-time Polymerase Chain Reaction

GAPDH

Glyceraldehyde 3-phosphate dehydrogenase

S. D

T. standard deviations

CCA

Canonical correlation analysis

BbkF

Benzo(b/k) fluoranthene

DBP

dibenzo(a,e)pyrene

\section{CAMs}

cell adhesion molecules

BP

biology process;

mAbs

monoclonal antibodies.

\section{Declarations}

\section{Ethics approval and consent to participate}

Animal studies were performed in accordance with the principles of laboratory animal care (NIH publication no. 85-23, revised 1985) and with approval by the Animal Ethical and Welfare Committee of West China Hospital (No. 2019272A).

\section{Consent for publication}

Not applicable.

\section{Not applicable.Availability of data and materials}

Not applicable. 


\section{Competing interests}

The authors declare that they have no competing interests.

\section{Funding}

This work was supported by National Natural Science Foundation of China (Nos. 81871890, 91859203 to W Li); CAMS Innovation Fund for Medical Science (No: 2019TX310002).

\section{Author information}

Affiliations

National Center for Geriatrics Clinical Medicine Research, Department of Geriatrics and Gerontology, West China Hospital, Sichuan University, Chengdu, 610041, China

College of oceanography, Hohai University, Nanjing, 210098, China.

Center of Precision Medicine, Precision Medicine Key Laboratory of Sichuan Province, West China Hospital, Sichuan University, Chengdu, 610041, China.

Department of Respiratory and Critical Care Medicine, West China Hospital, Sichuan University, Chengdu, Sichuan, 610041, China.

Contributions

S.D performed the experiments and generated data. Z.W helped with the data collection and analysis. Y.Y and T.G helped data analysis. W.L are the guarantor of this work, had full access to all the data, and takes full responsibility for the integrity of data and the accuracy of data analysis. The author(s) read and approved the final manuscript.

Corresponding author

Weimin Li, E-mail address: weimin003@163.com.

\section{Acknowledgements}

We are grateful to the teachers Xijin Yang, Xiaoting Chen and Linhui Yang of the animal experimental center of West China Hospital for their help in mouse feeding and experiment. We thank Bo Su for his guidance on microCT imaging of mice.

\section{References}

1. Xing YF, Xu YH, Shi MH, Lian YX. The impact of PM2.5 on the human respiratory system. Journal of Thoracic Disease. 2016;8:E69-74. 
2. Cohen AJ, Brauer M, Burnett R, Anderson HR, Frostad J, Estep K, Balakrishnan K, Brunekreef B, Dandona L, Dandona R, Feigin V, Freedman G, Hubbell B, Jobling A, Kan H, et al. Estimates and 25-year trends of the global burden of disease attributable to ambient air pollution: an analysis of data from the Global Burden of Diseases Study 2015. The Lancet. 2017;389:1907-18.

3. Feng S, Gao D, Liao F, Zhou F, Wang X. The health effects of ambient PM2.5 and potential mechanisms. Ecotox Environ Safe. 2016;128:67-74.

4. Johannson KA. Air pollution exposure and IPF: Prevention when there is no cure. Thorax. 2018;73:103-4.

5. Williams AM, Phaneuf DJ, Barrett MA, Su JG. Short-term impact of PM2.5 on contemporaneous asthma medication use: Behavior and the value of pollution reductions. Proceedings of the National Academy of Sciences. 2019;116:5246-53.

6. Hart JE, Grady ST, Laden F, Coull BA, Koutrakis P, Schwartz JD, Moy ML, Garshick E. Effects of Indoor and Ambient Black Carbon and PM2.5 on Pulmonary Function among Individuals with COPD. Environ Health Persp. 2018;126:127001-8.

7. Phua J, Badia JR, Adhikari NKJ, Friedrich JO, Fowler RA, Singh JM, Scales DC, Stather DR, Li A, Jones A, Gattas DJ, Hallett D, Tomlinson G, Stewart TE, Ferguson ND. Has Mortality from Acute Respiratory Distress Syndrome Decreased over Time?: A Systematic Review. Am J Resp Crit Care. 2009;179:220-7.

8. Lim SS, Vos T, Flaxman AD, Danaei G, Shibuya K, Adair-Rohani H, Amann M, Anderson HR, Andrews KG, Aryee M, Atkinson C, Bacchus LJ, Bahalim AN, Balakrishnan K, Balmes J, et al. A comparative risk assessment of burden of disease and injury attributable to 67 risk factors and risk factor clusters in 21 regions, 1990-2010: A systematic analysis for the Global Burden of Disease Study 2010. The Lancet. 2012;380:2224-60.

9. Zhou M, Wang H, Zeng X, Yin P, Zhu J, Chen W, Li X, Wang L, Wang L, Liu Y, Liu J, Zhang M, Qi J, Yu S, Afshin A, et al. Mortality, morbidity, and risk factors in China and its provinces, 1990-2017: a systematic analysis for the Global Burden of Disease Study 2017. Lancet (London, England). 2019;394:1145-58.

10. Zheng R, Tao L, Jian H, Chang Y, Cheng Y, Feng Y, Zhang H. NLRP3 inflammasome activation and lung fibrosis caused by airborne fine particulate matter. Ecotox Environ Safe. 2018;163:612-9.

11. Yuan W, Fulgar CC, Sun X, Vogel CFA, Wu C, Zhang Q, Bein KJ, Young DE, Li W, Wei H, Pinkerton KE. In vivo and in vitro inflammatory responses to fine particulate matter (PM2.5) from China and California. Toxicol Lett. 2020;328:52-60.

12. Yue H, Ji X, Li G, Hu M, Sang N. Maternal Exposure to PM2.5 Affects Fetal Lung Development at Sensitive Windows. Environ Sci Technol. 2020;54:316-24.

13. Xu Z, Li Z, Liao Z, Gao S, Hua L, Ye X, Wang Y, Jiang S, Wang N, Zhou D, Deng X. PM2.5 induced pulmonary fibrosis in vivo and in vitro. Ecotox Environ Safe. 2019;171:112-21.

14. Geng J, Liu H, Ge P, Hu T, Zhang Y, Zhang X, Xu B, Wang B, Xie J. PM2.5 promotes plaque vulnerability at different stages of atherosclerosis and the formation of foam cells via TLR4/MyD88/NFKB pathway. Ecotox Environ Safe. 2019;176:76-84.

15. Yue W, Tong L, Liu X, Weng X, Chen X, Wang D, Dudley SC, Weir EK, Ding W, Lu Z, Xu Y, Chen Y. Short term Pm2.5 exposure caused a robust lung inflammation, vascular remodeling, and exacerbated transition from left ventricular failure to right ventricular hypertrophy. Redox Biology. 2019;22:101161. 
16. Wang H, Shen X, Tian G, Shi X, Huang W, Wu Y, Sun L, Peng C, Liu S, Huang Y, Chen X, Zhang F, Chen Y, Ding W, Lu Z. AMPKa2 deficiency exacerbates long-term PM2.5 exposure-induced lung injury and cardiac dysfunction. Free Radical Bio Med. 2018;121:202-14.

17. Zhou L, Su X, Li B, Chu C, Sun H, Zhang N, Han B, Li C, Zou B, Niu Y, Zhang R. PM2.5 exposure impairs sperm quality through testicular damage dependent on NALP3 inflammasome and miR-183/96/182 cluster targeting FOXO1 in mouse. Ecotox Environ Safe. 2019;169:551-63.

18. Xie M, Wang G, Hu S, Han Q, Xu Y, Gao Z. Aliphatic alkanes and polycyclic aromatic hydrocarbons in atmospheric PM10 aerosols from Baoji, China: Implications for coal burning. Atmos Res. 2009;93:840-8.

19. Zhang Y, Cao F. Fine particulate matter (PM2.5) in China at a city level. Sci. Rep.-UK. 2015;5.

20. Zhang Y, Shuai C, Bian J, Chen X, Wu Y, Shen L. Socioeconomic factors of PM2.5 concentrations in 152 Chinese cities: Decomposition analysis using LMDI. J Clean Prod. 2019;218:96-107.

21. Turner MC, Krewski D, Pope CA, Chen Y, Gapstur SM, Thun MJ. Long-term Ambient Fine Particulate Matter Air Pollution and Lung Cancer in a Large Cohort of Never-Smokers. Am J Resp Crit Care. 2011;184:137481.

22. Organization $\mathrm{WH}$. WHO air quality guidelines for particulate matter, ozone, nitrogen dioxide and sulfur dioxide, 2006.

23. Lei X, Muscat JE, Huang Z, Chen C, Xiu G, Chen J. Differential transcriptional changes in human alveolar epithelial A549 cells exposed to airborne PM2.5 collected from Shanghai, China. Environ Sci Pollut R. 2018;25:33656-66.

24. Yang B, Li X, Chen D, Xiao C. Effects of fine air particulates on gene expression in non-small-cell lung cancer. Adv Med Sci-Poland. 2017;62:295-301.

25. Wang H, Shen X, Liu J, Wu C, Gao J, Zhang Z, Zhang F, Ding W, Lu Z. The effect of exposure time and concentration of airborne PM2.5 on lung injury in mice: A transcriptome analysis. Redox Biology. 2019;26:101264.

26. Badyda AJ, Grellier J, Dąbrowiecki P. Ambient. PM2.5 Exposure and Mortality Due to Lung Cancer and Cardiopulmonary Diseases in Polish Cities. In: Pokorski M, editor. Respiratory Treatment and Prevention. Cham: Springer International Publishing; 2017. pp. 9-17.

27. Ning J, Li P, Zhang B, Han B, Su X, Wang Q, Wang X, Li B, Kang H, Zhou L, Chu C, Zhang N, Pang Y, Niu Y, Zhang R. miRNAs deregulation in serum of mice is associated with lung cancer related pathway deregulation induced by PM2.5. Environ. Pollut. 2019;254:112875.

28. Lin C, Tsai C, Sun Y, Hsieh W, Lin Y, Chen C, Lin C. Instillation of particulate matter 2.5 induced acute lung injury and attenuated the injury recovery in ACE2 knockout mice. Int J Biol Sci. 2018;14:253-65.

29. Qin F, Xu M, Wang Z, Han Z, Dong Y, Zhao J. Effect of aerobic exercise and different levels of fine particulate matter (PM2.5) on pulmonary response in Wistar rats. Life Sci. 2020;254:117355.

30. Rivas-Santiago CE, Sarkar S, Cantarella PT, Osornio-Vargas Á, Quintana-Belmares R, Meng Q, Kirn TJ, Ohman Strickland P, Chow JC, Watson JG, Torres M, Schwander S. Air pollution particulate matter alters antimycobacterial respiratory epithelium innate immunity. Infect Immun. 2015;83:2507-17.

31. Bauer RN, Diaz-Sanchez D, Jaspers I. Effects of air pollutants on innate immunity: the role of Toll-like receptors and nucleotide-binding oligomerization domain-like receptors. J Allergy Clin Immunol. 2012;129:14-26. 
32. Liu S, Zhang W, Zhang F, Roepstorff P, Yang F, Lu Z, Ding W. TMT-Based Quantitative Proteomics Analysis Reveals Airborne PM2.5-Induced Pulmonary Fibrosis. Int. J. Env. Res. Pub. He. 2019;16.

33. Kwak K, Akkaya M, Pierce SK. B cell signaling in context. Nat Immunol. 2019;20:963-9.

34. Von Hoegen I, Nakayama E, Parnes JR. Identification of a human protein homologous to the mouse Lyb-2 B cell differentiation antigen and sequence of the corresponding cDNA. J Immunol. 1990;144:4870-7.

35. Kumanogoh A, Watanabe C, Lee I, Wang X, Shi W, Araki H, Hirata H, Iwahori K, Uchida J, Yasui T, Matsumoto M, Yoshida K, Yakura H, Pan C, Parnes JR, Kikutani H. Identification of CD72 as a Lymphocyte Receptor for the Class IV Semaphorin CD100: A Novel Mechanism for Regulating B Cell Signaling. Immunity. 2000;13:621-31.

36. Kumanogoh A, Kikutani $\mathrm{H}$. The CD100-CD72 interaction: a novel mechanism of immune regulation. Trends Immunol. 2001;22:670-6.

37. Gordon J. B-cell signalling via the C-type lectins CD23 and CD72. Trends Immunol. 1994;15:411-7.

38. Nomura T, Han H, Howard MC, Yagita H, Yakura H, Honjo T, Tsubata T. Antigen receptor-mediated B cell death is blocked by signaling via CD72 or treatment with dextra n sulfate and is defective in autoimmunityprone mice. Int Immunol. 1996;8:867-75.

39. Katira A, Kamal M, Gordon J. Occupancy of CD72 (the CD5 counterstructure) enhances inteleukin-4dependent CD23 expression in resting B lymphocytes. Immunology. 1992;76:422-6.

40. Lyu M, Hao Y, Li Y, Lyu C, Liu W, Li H, Xue F, Liu X, Yang R. Upregulation of CD72 expression on CD19 + CD27 + memory B cells by CD40L in primary immune thrombocytopenia. Brit J Haematol. 2017;178:30818.

41. Li G, Liu H, Guan W, Xu H, Wu B, Feng J, Sun L. A mutation in PIK3CD gene causing pediatric systemic lupus erythematosus: A case report. Medicine. 2019;98:e15329.

42. Dymacek J, Snyder-Talkington BN, Porter DW, Mercer RR, Wolfarth MG, Castranova V, Qian Y, Guo NL. mRNA and miRNA Regulatory Networks Reflective of Multi-Walled Carbon Nanotube-Induced Lung Inflammatory and Fibrotic Pathologies in Mice. Toxicol Sci. 2014;144:51-64.

43. Amrani Y, Tliba O, Krymskaya VP, Sims MW, Panettieri RA. Chapter 18 - Airway Smooth Muscle. in: Barnes P J, Drazen J M, Rennard S I, Thomson N C(Eds.) Asthma and COPD (Second Edition), Academic Press, Oxford, 2009, pp. $225-39$.

44. DeLisser HM, Albelda SM. The Function of Cell Adhesion Molecules in Lung Inflammation: More Questions Than Answers. Am J Resp Cell Mol. 1998;19:533-6.

45. Tedder TF, Tuscano J, Sato S, Kehrl JH. CD22, A B LYMPHOCYTE-SPECIFIC ADHESION MOLECULE THAT REGULATES ANTIGEN RECEPTOR SIGNALING*. Annu Rev Immunol. 1997;15:481-504.

46. Inaba H, Pui C. Immunotherapy in pediatric acute lymphoblastic leukemia. Cancer Metast Rev. 2019;38:595-610.

47. Okona-Mensah KB, Battershill J, Boobis A, Fielder R. An approach to investigating the importance of high potency polycyclic aromatic hydrocarbons (PAHs) in the induction of lung cancer by air pollution. Food Chem Toxicol. 2005;43:1103-16.

48. Pope IIICA, Burnett RT, Thun MJ, Calle EE, Krewski D, Ito K, Thurston GD. Lung cancer, cardiopulmonary mortality, and long-term exposure to fine particulate air pollution. J Am Med Assoc. 2002;287:1132-41. 
49. Xia Z, Duan X, Tao S, Qiu W, Liu D, Wang Y, Wei S, Wang B, Jiang Q, Lu B, Song Y, Hu X. Pollution level, inhalation exposure and lung cancer risk of ambient atmospheric polycyclic aromatic hydrocarbons (PAHs) in Taiyuan, China. Environ Pollut. 2013;173:150-6.

50. WHO W H O, Environmental Health Criteria 202. Selected non-heterocyclic polycyclic aromatic hydrocarbons. International Programme on Chemical Safety, World Health Organisation, Geneva: IPCS; 1998.

51. US EPA E P A. Carcinogen Assessment of Coke Oven Emissions. Final report. Washington, DC: Office of Health and Environmental Assessment; 1984.

52. Bhattacharya S, Chakraborty P, Roy SS. Dibenz[a,h]anthracene. In: Wexler P, editor. Encyclopedia of Toxicology (Third Edition). Oxford: Academic Press; 2014. pp. 62-6.

53. Yan D, Wu S, Zhou S, Tong G, Li F, Wang Y, Li B. Characteristics, sources and health risk assessment of airborne particulate PAHs in Chinese cities: A review. Environ Pollut. 2019;248:804-14.

54. Zhang Y, Chen J, Yang H, Li R, Yu Q. Seasonal variation and potential source regions of PM2.5-bound PAHs in the megacity Beijing, China: Impact of regional transport. Environ Pollut. 2017;231:329-38.

55. Ma WL, Liu LY, Jia HL, Yang M, Li YF. PAHs in Chinese atmosphere Part I: Concentration, source and temperature dependence. Atmos Environ. 2018;173:330-7.

56. Fontes T, Li P, Barros N, Zhao P. Trends of PM2.5 concentrations in China: A long term approach. J Environ Manage. 2017;196:719-32.

57. Tao S, Ru MY, Du W, Zhu X, Zhong QR, Li BG, Shen GF, Pan XL, Meng WJ, Chen YL, Shen HZ, Lin N, Su S, Zhuo SJ, Huang TB, et al. Quantifying the rural residential energy transition in China from 1992 to 2012 through a representative national survey. Nature Energy. 2018;3:567-73.

58. Takada H, Onda T, Ogura N. Determination of polycyclic aromatic hydrocarbons in urban street dusts and their source materials by capillary gas chromatography. Environ Sci Technol. 1990;24:1179-86.

59. Chu C, Zhang H, Cui S, Han B, Zhou L, Zhang N, Su X, Niu Y, Chen W, Chen R, Zhang R, Zheng Y. Ambient PM2.5 caused depressive-like responses through Nrf2/NLRP3 signaling pathway modulating inflammation. J Hazard Mater. 2019;369:180-90.

60. Du W, Chen Y, Zhu X, Zhong Q, Zhuo S, Liu W, Huang Y, Shen G, Tao S. Wintertime air pollution and health risk assessment of inhalation exposure to polycyclic aromatic hydrocarbons in rural China. Atmos Environ. 2018;191:1-8.

61. Gaston B, May WJ, Sullivan S, Yemen S, Marozkina NV, Palmer LA, Bates JN, Lewis SJ. Essential role of hemoglobin beta-93-cysteine in posthypoxia facilitation of breathing in conscious mice. Journal of applied physiology (Bethesda, Md.: 1985). 2014;116:1290-9.

62. Schulze F, Gao X, Virzonis D, Damiati S, Schneider MR, Kodzius R. Air Quality Effects on Human Health and Approaches for Its Assessment through Microfluidic Chips. Genes. 2017;8:244.

63. Vandesompele J, De Preter K, Pattyn F, Poppe B, Van Roy N, De Paepe A, Speleman F. Accurate normalization of real-time quantitative RT-PCR data by geometric averaging of multiple internal control genes. Genome biology. 2002;3:H34.

\section{Figures}



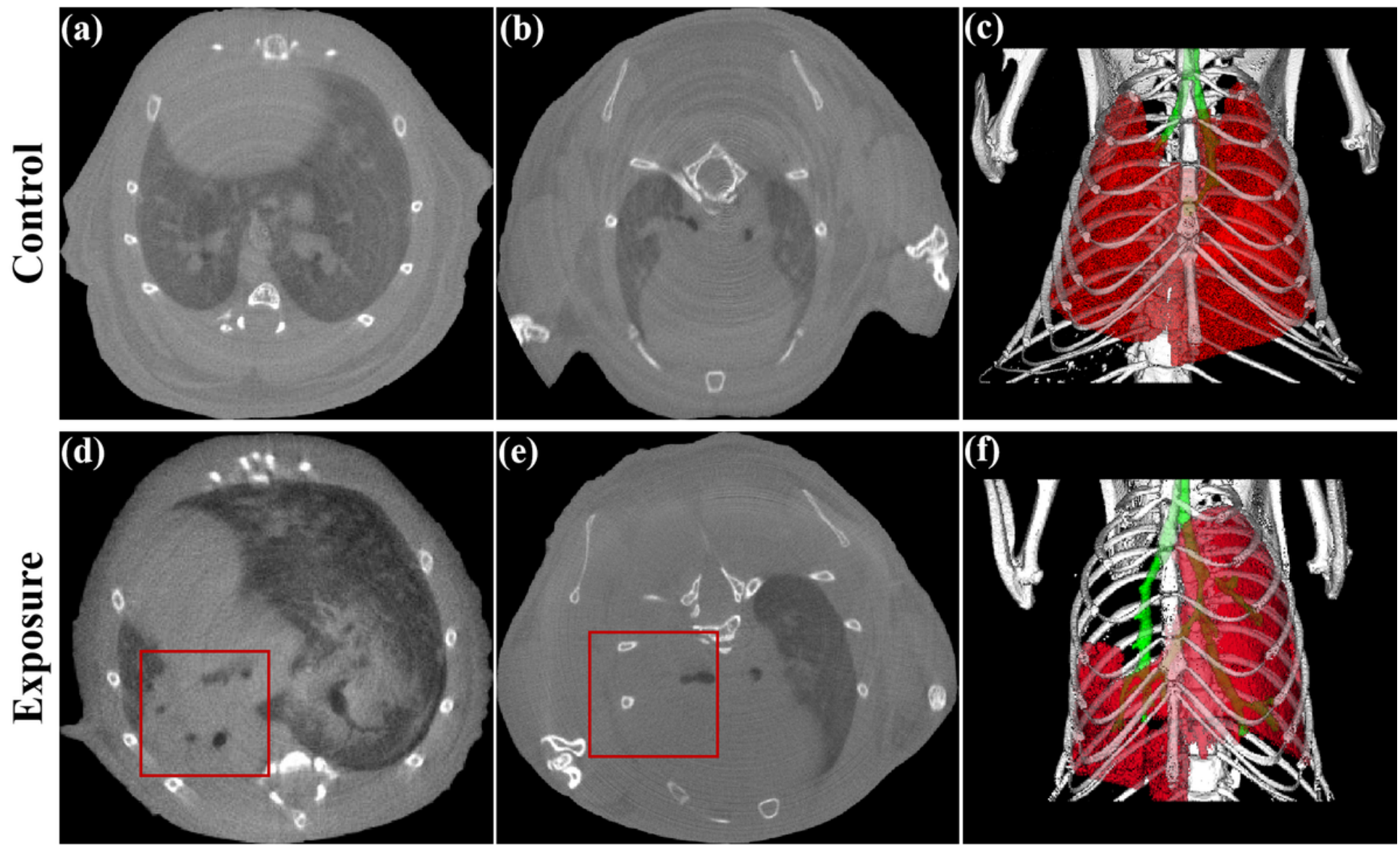

Figure 1

PM2.5 induced obvious pulmonary dysfunction in male Balb/C mice lung tissues. $(\mathrm{a}, \mathrm{b})$ Micro-CT images of mice lungs from the control; (c) 3D reconstruction of mice lung from the control; (d, e) Micro-CT images of mice lungs from exposure group; (f) 3D reconstruction of mice lung from exposure group. 

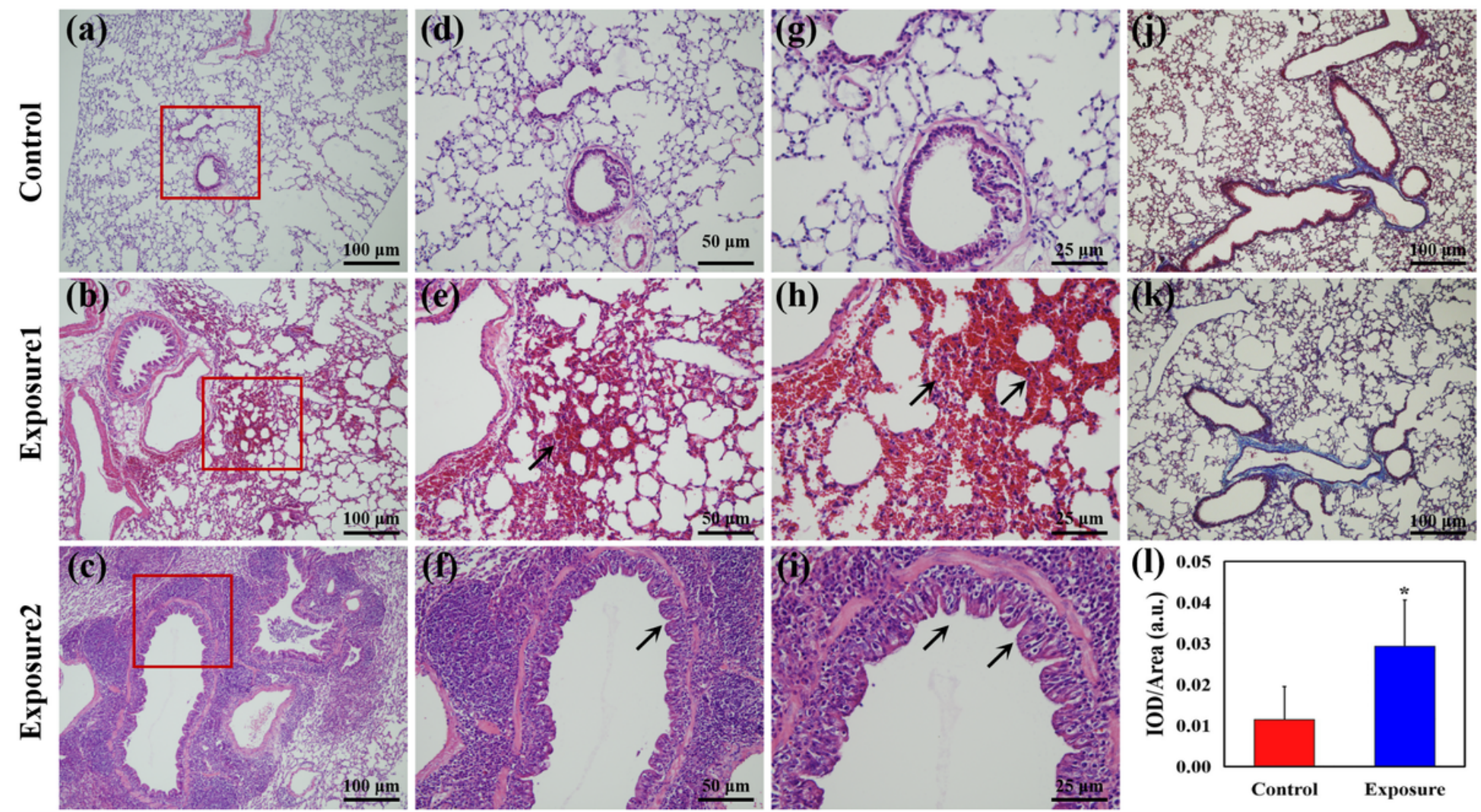

Figure 2

PM2.5 induced pulmonary inflammation and fibrosis in male Balb/C mice lung tissues. (a-c) 100x HE staining of mice lung tissue; (d-f) 200x HE staining of mice lung tissue; ( $\mathrm{g}-\mathrm{i}) 400 \times \mathrm{HE}$ staining of mice lung tissue; (j, $\mathrm{k}$ ) $100 \times$ Masson trichrome staining of mice lung tissue; (I) semiquantitative analysis of fibrosis levels of mice lung tissue. Red rectangle: target zone of lung tissue; arrows: inflammatory infiltration and bronchial wall thickening of lung tissue. (100x, Bar: $100 \mu \mathrm{m}$; 200x, Bar: $50 \mu \mathrm{m}$; 400x, Bar: $25 \mu \mathrm{m}$ ). 

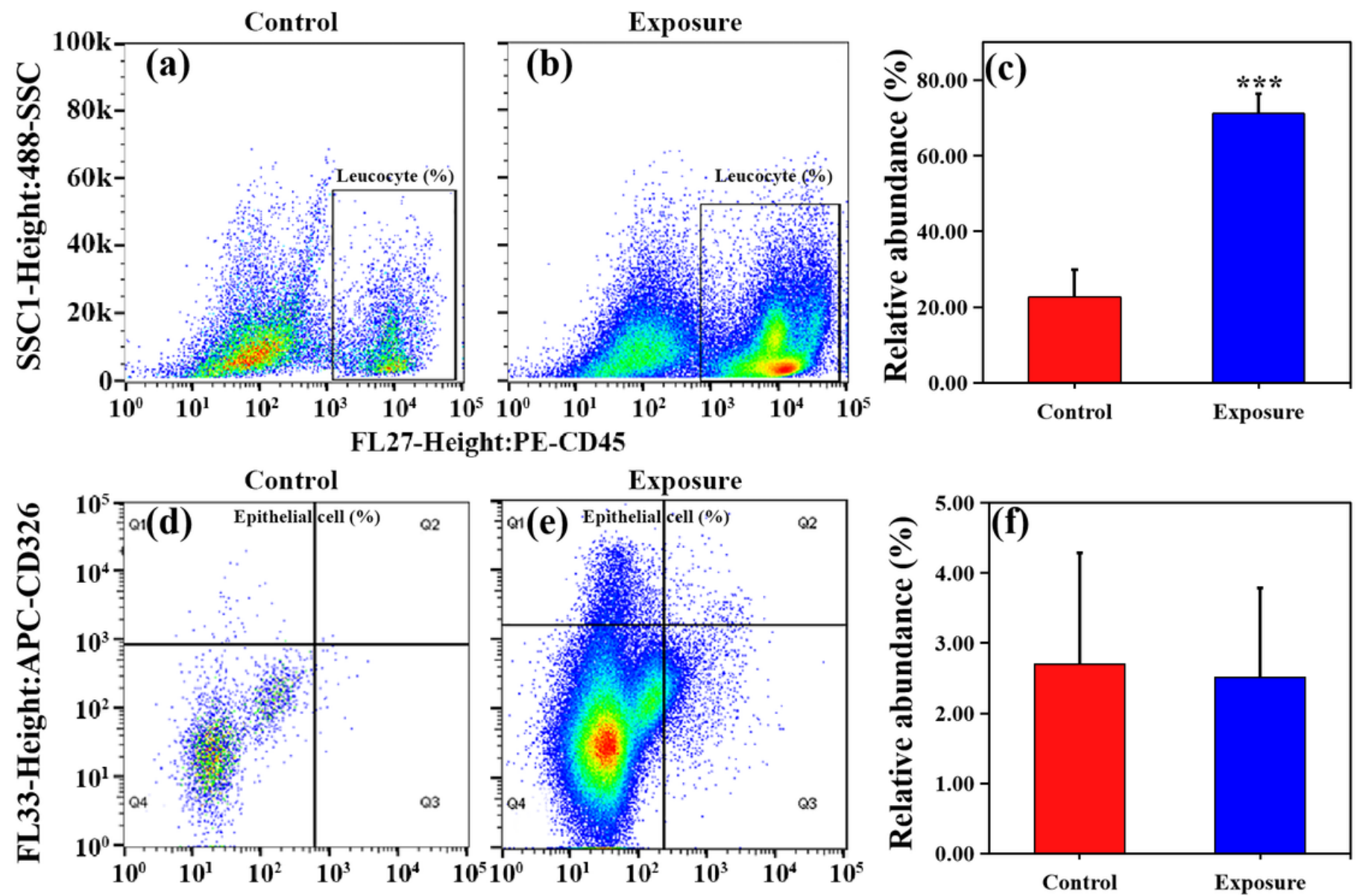

Figure 3

PM2.5 induced leucocyte proliferation in male Balb/C mice lung tissues. (a-c) relative abundance of leucocyte CD 45+ in mice lung tissue; (d-f) relative abundance of epithelial cells CD45-/CD31-/CD326+ in mice lung tissue. 
(a)

(b)

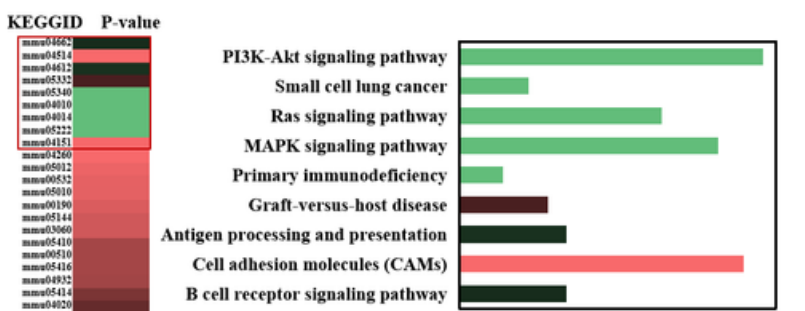

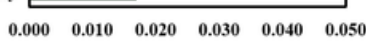
Gene ratio
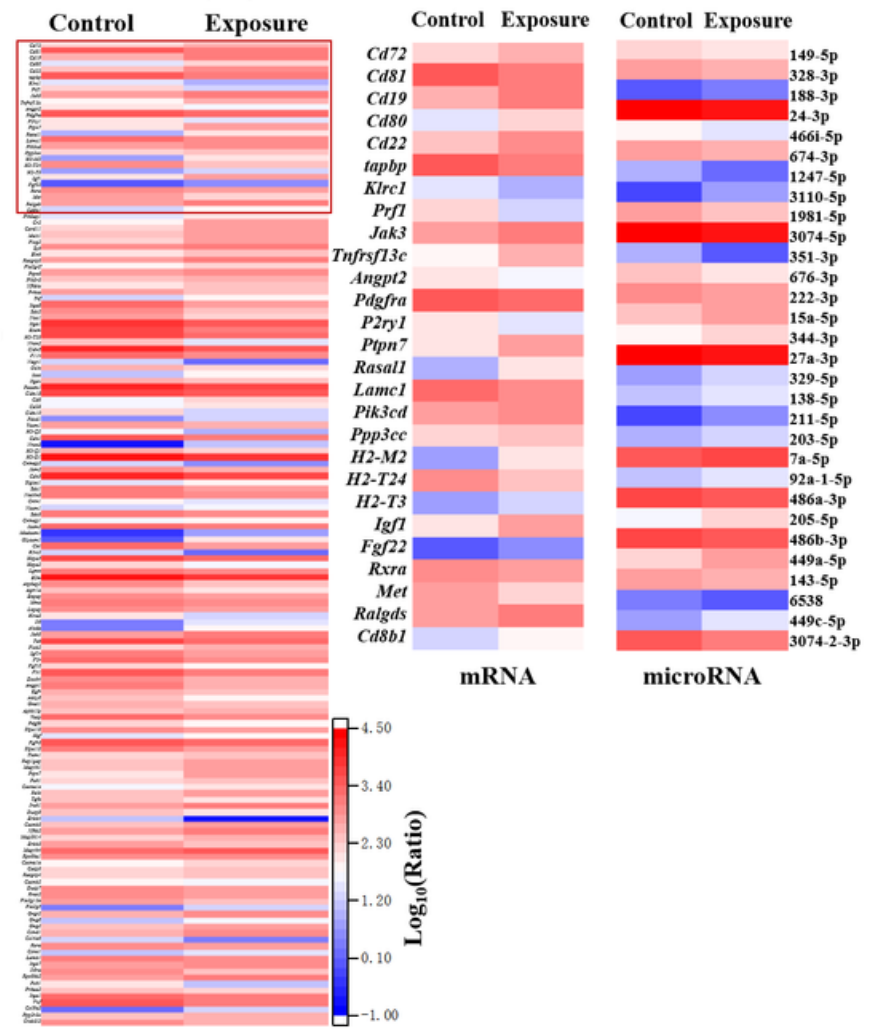

microRNA

(d)
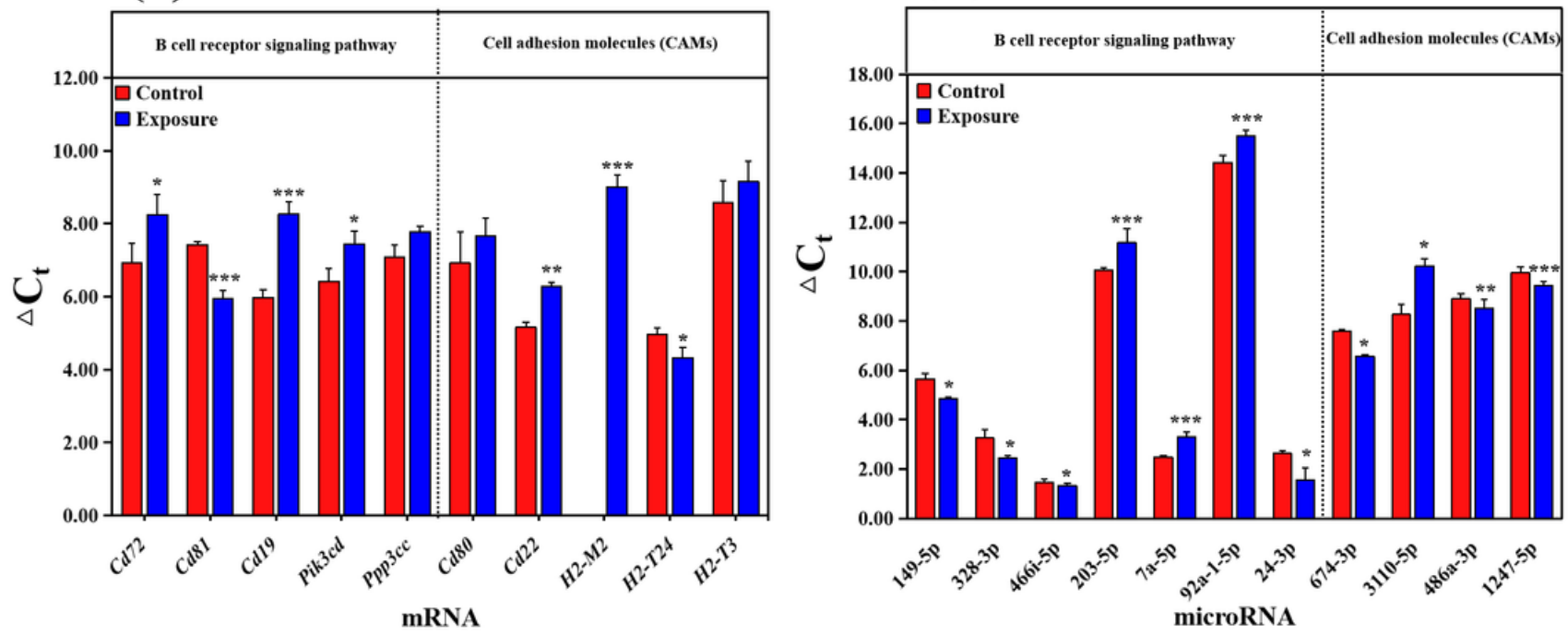

Figure 4

Some results of the transcriptomics analysis and the RT-qPCR. (a) different KEGG pathway annotated by DEGs between control and exposure groups and the selected KEGG pathway in mice lung tissue; (b) comparison of expression profile associated with the selected KEGG pathway in mice lung tissue and the selected genes and microRNA; (c, d) Relative expression ( $\triangle$ Ct values) of genes and associated microRNA involved into $B$ cell receptor signaling pathway and cell adhesion molecules (CAMs) by RT-qPCR assay. 
CD19
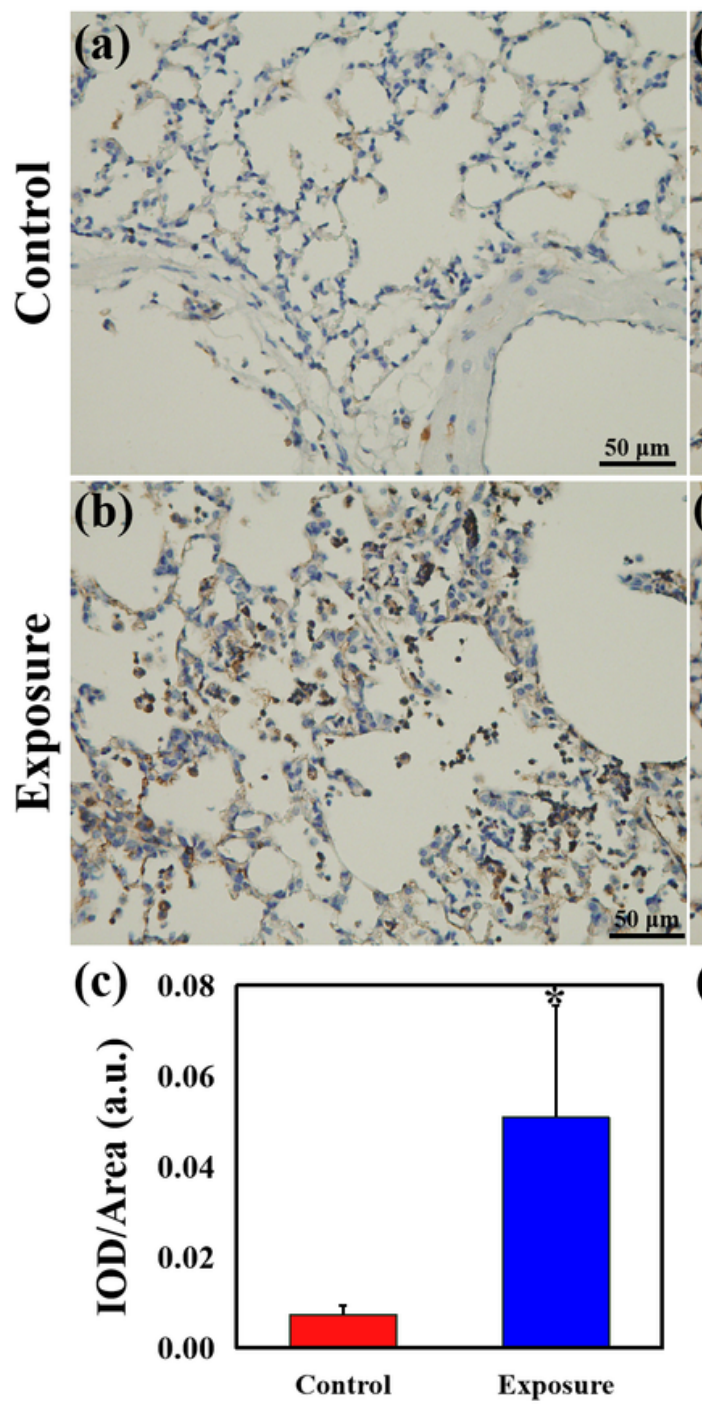

CD81
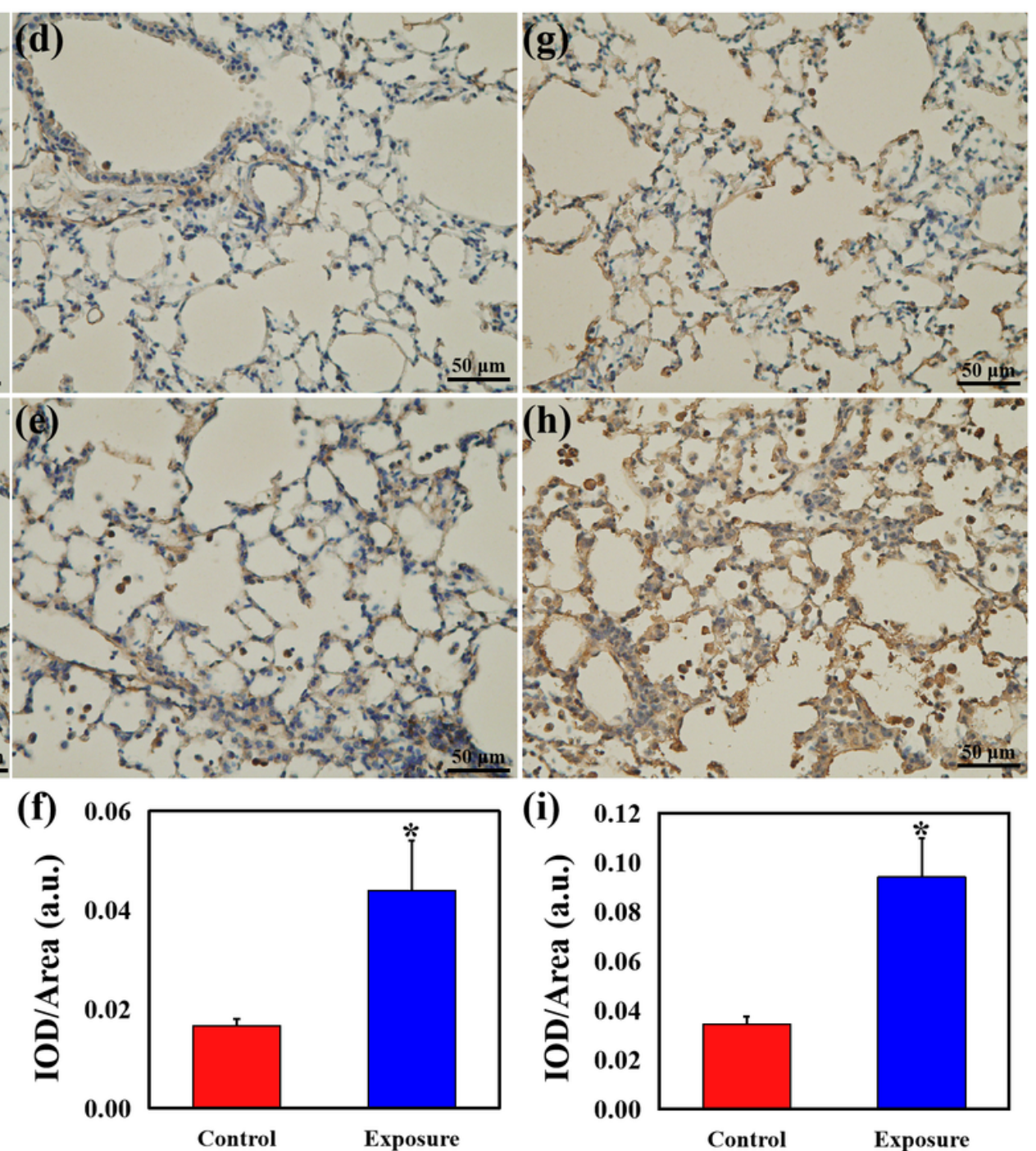

PIK3CD
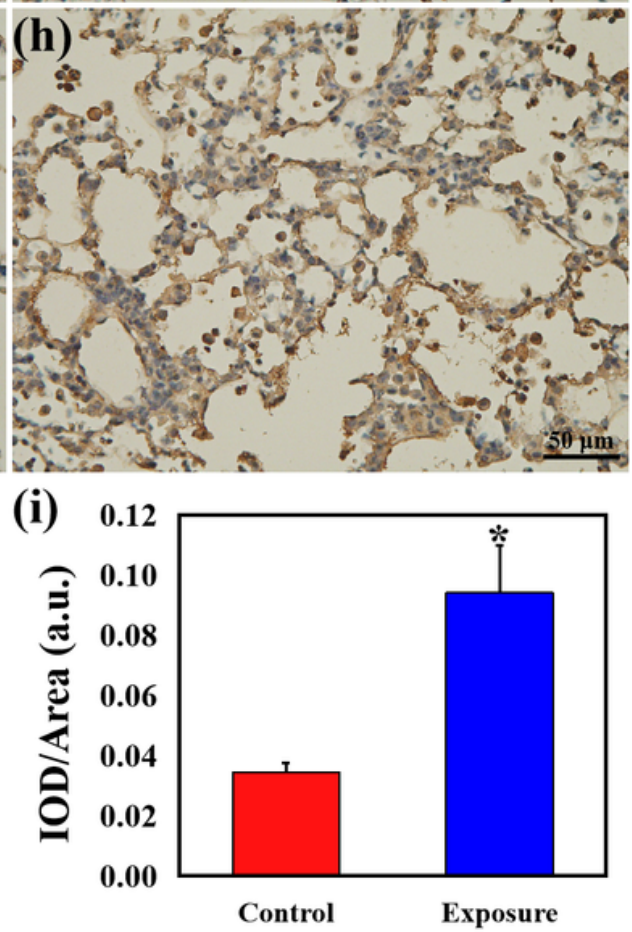

Figure 5

The changes of protein expression of CD19, CD82, and PIK3CD induced by PM2.5 using

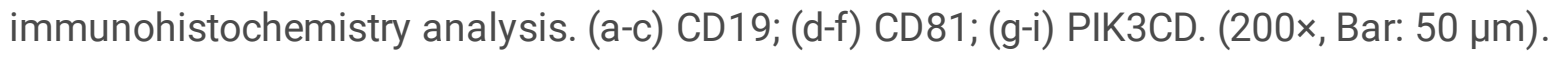

\section{Supplementary Files}

This is a list of supplementary files associated with this preprint. Click to download.

- supportinginformation.doc 